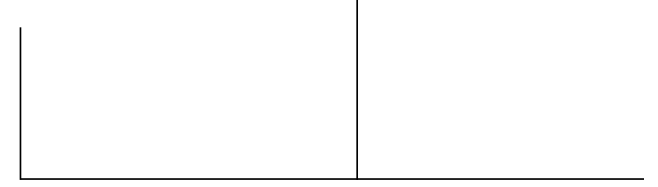

Rev. Latinoam. Psicop. Fund. VI, 3, 164-179

\title{
Hospicio de São Paulo Fragmentos de Psychiatria*
}

\author{
Dr. Franco da Rocha
}

\section{A quem ler}

Esta espécie de prólogo tem por fim servir de cordão sanitário ou de profilaxia de defesa contra certa crítica, que costuma julgar tudo ruim, porque não traz novidade.

Res ardua medicinae novitatem darem, diz E. Monin.

A carestia de jornais científicos entre nós explica este sistema de folhetos cheios de fragmentos.

O primeiro capítulo deste foi escrito com o intuito de dar uma idéia rápida, em traços gerais, de certas espécies de degenerados. Não foi escrito para os que sabem, está claro; mas para os que conhecem mal os desequilibrados, e não têm tempo de ler os livros extensos sobre o assunto.

Julguei que uma dose homeopática de literatura daria bom resultado, aguçando a curiosidade do leitor para estes estudos; por isso formulei algumas rápidas considerações sobre os artistas nevropatas. Em relação aos literatos limitome apenas a indicar os autores que podem servir para instruir os que quiserem conhecer melhor o assunto.

* São Paulo: Typ. Lithograhia Ribeiro, 1895. 
As desordens da inteligência foram sempre o ponto de preferência para quase todos os literatos. Não falando nos literatos europeus, que são muitos, E. Zola, os Goncourt, C. Castello Branco, etc., só entre os nossos, que são poucos, encontramos os escritos de Machado de Assis, Aluizio Azevedo, Lucio de Mendonça, Horacio de Carvalho, D. Julia Lopes (uma das poucas senhoras brasileiras que ocupam as horas de lazer em proveitoso estudo) e outros.

Só pela leitura destas páginas o leitor não apanhará grandes conhecimentos de psicologia patológica; mas suponha que deu um passeio pelo Hospício e palestrou um pouco com um dos médicos.

Não reuni uma série de observações clínicas para não ser muito longo este trabalho.

Diversas páginas deste folheto prestam-se a um desenvolvimento que daria o décuplo do volume, o que lhe faria perder uma das boas qualidades para ser lido; é essa a razão porque muitos pontos interessantes são aqui tratados ... a velocípede.

São Paulo, 1895

Dr. Franco da Rocha

\section{Degeneração}

Aceita qualquer das teorias sobre a hereditariedade, mórbida ou normal, ${ }^{1} \mathrm{o}$ fato em si está hoje exuberantemente provado, o que dispensa a apresentação de fatos no mesmo sentido.

A acumulação de defeitos por herança mórbida, na esfera das funções superiores do sistema nervoso, constitui a degeneração psíquica hereditária.

A expressão acima grifada deve fazer compreender que a mesma degeneração pode ser também, adquirida, fato que não se pode negar.

Depois da tríade notável - trabalhos de Prosper Lucas, de Morel e de Moreau (de Tours) - sobre a herança mórbida, principalmente dos dois últimos, este capítulo da patologia mental tem se desenvolvido rapidamente, assumindo mesmo as proporções de ponto capital na etiologia da loucura.

1. Todas as teorias em relação a este assunto podem ser consideradas provisórias, como o próprio Darwin considerou a sua pangenese, ou a teoria das gêmulas. (...) No estado atual da ciência, as teorias sobre a hereditariedade não têm caráter positivo; todas as concepções até hoje expostas podem ser combatidas. Mas isso não é razão para dizer-se, como muitos, que a ciência não vale nada... 
Trabalhos importantes, na França, Alemanha, Inglaterra e Itália, elevaram este estudo à altura que ele realmente merece. Os escritos são inúmeros e diversos autores tornaram-se salientes, como Féré, Magnan, Legrain, Krafft-Ebing, Schüle, Lombroso, Morselli, Maudsley e outros muitos.

Na literatura de todos os países encontra-se uma fonte riquíssima para o estudo da degeneração; e é interessante observar-se o assunto sob esse ponto de vista.

Por um lado, espíritos clarividentes, observadores de fina têmpera, como Cervantes, Shakespeare ${ }^{2}$ e outros, fornecem, nos seus personagens, tipos de degenerados estudados com a perfeição que só é dada a poucos homens. O herói de La Mancha, por exemplo, é um tipo tão perfeito e acabado, que os melhores tratados de psiquiatria não deixam de citá-lo.

Por outro lado, homens de talento também inegável mostraram que este predicado não era incompatível com a degeneração, porque os seus escritos, pondo a descoberto o respectivo estado mental, não deixam dúvida sobre isso. Edgar Poe não está isolado na literatura; basta lembrar o seu tradutor francês, Baudelaire. $^{3}$

Entre nós, infelizmente, existem escritos que denunciam claramente os seus autores.

2. Paul de St. Victor (Les Deux masques, vol. 3) refere-se a Falstaff com admirável precisão: “On ne lui en veut pas plus de ses turpitudes qu'à un poureau de se vautrer dans la fange. L'absense du sens moral est si bien constaté chez lui, qu'elle le rend presque irresponsable. Son immoralité n'a rien de reflexie; elle est toute spontanée et tout animale. Il va au vol et á la crapule, comme la bête va à sa proie ou à sa pâture.” Os grifos são meus. "Ce gros homme réprésente, à sa manière, la loi naturelle dans son opposition à la loi humaine. Il ne discerne pas plus le Juste et l'Injuste, que l'enfant qui vient de naitre ne distingue sa droite de sa gauche," etc.

Essas considerações do notável crítico bastam para provar o que era Falstaff, o debochado irresponsável, de senso moral completamente embotado. Limito-me a esta citação, deixando outros tipos, como Hamlet, para não me tornar prolixo. (...)

3. Moreau (de Tours) tem um ligeiro estudo, bem feito, sobre Edgar Poe, nos Annaes Med Psych, 1894. (...) Baudelaire tem versos que com muita justeza ele mesmo intitula "Obsession" - (Fleurs du mal). (...)

Muitos degenerados são verdadeiros judeus errantes. Conheço um nesse gênero, e que esteve algum tempo no Hospício, em período de excitação. O dr. Meige (th. de Paris) estudou uma espécie de neurastênicos viajantes, e conclui que a lenda do Judeu Errante é uma tradição popular de um desses indivíduos. Essas viagens repetidas têm um fim evidente - melhorar de estado - o que não conseguem. A eles se aplicam, a propósito, as palavras do padre A. Vieira: "Como quereis melhorar de lugar, se vos levais a vós convosco?” (...)

Tinha razão Gautier: Poe bebia como um louco, não como um bêbado. O álcool é a pedra de toque dos desequilibrados, diz Féré. Era adorado por Baudelaire, que por sua vez era um toxicófago e morreu em estado agudo de loucura. (...) 


\section{CLÁSSICO S DA \\ PSICOPATOLOGIA \\ ano $\mathrm{VI}$, n. 3, set/ 2003}

Ainda não há muito tempo, fez ruído na nossa literatura um romance aqui publicado, que patenteia, a par de belíssimas descrições, de correta e fulgurante linguagem, um erotismo impudente, doentio, uma depravação do apetite genésico, um eretismo cerebral, manifestando-se pela produção exagerada de imagens voluptuosas intensas. ${ }^{4}$

Muitos poetas, consciente ou inconscientemente, em busca de sensações para satisfazer o sistema nervoso degenerado, têm acabado a existência como verdadeiros odres de álcool.

No Brasil, onde os literatos não são muito numerosos, não seria muito difícil apontar mais de um caso nesse gênero. ${ }^{5}$ Não creio que seja isso o resultado de imitação, mas sim de necessidade de excitantes violentos.

$\mathrm{Na}$ nossa literatura encontram-se personagens espirituosamente bem pintados por escritores de talento e mérito, como Machado de Assis, Lucio Mendonça e outros.

Não sendo estas observações trabalho de crítica (para a qual absolutamente não tenho competência) lembro apenas aos que quiserem se divertir nesta especialidade, o excelente livro de Max Nordau - a Degenerescência.

Pondo de parte a maneira dúbia de interpretar a teoria da degeneração, ora aceitando o atavismo, ora a degeneração patológica (a verdadeira), questões puramente teóricas, esse livro é magnífico como aplicação das noções da psiquiatria à literatura.

Aí o leitor encontrará, dissecados por implacável bisturi, diversos tipos notáveis da literatura e arte modernas: Wagner, Dante-Rossetti, Th. Gautier, Baudelaire, Tolstoi, Rollinat, S. Péladan (que o autor nos dá como um perfeito Don Quixote), Ibsen, Huysmans, etc. ${ }^{6}$

4. Se a Mlle. De Maupin de Th. Gautier não se livra desta acusação, que dizer d'A Carne?

5. A Noite na taverna é de um autor que deixou fama, tanto como homem de talento como de alcoolista. Talento de elite inegavelmente, aí estão as suas obras impressas como brilhante atestado. A célebre Chácara da Figueira, em São Paulo, foi o Parnaso de onde saiu muita produção literária inspirada à luz do cognac.

6. O que diz Max Nordau em relação a Tolstoi tem cabimento justo a mais de um indivíduo aqui no Brasil: Vejamos - p. 295, $1^{\circ}$ vol.: "E, na Minha Confissão, Tolstoi diz expressamente: eu sentia que não estava completamente são em relação à inteligência. Seu sentimento era justo. Sofria de loucura da dúvida ou do ceticismo, observada muito comumente nos degenerados superiores. Lombroso menciona entre os seus loucos de gênio essa espécie de monomania: quase todos (diz Lombroso) são dolorosamente perseguidos pelas dúvidas religiosas, que excitam o espírito e obcecam como um crime a consciência timorata e o coração doentio.” (Gênio e loucura, p. 354).

Leiam agora estes tópicos de artigo publicado num jornal aqui de São Paulo: 
R E V I S T A

LATINOAMERICANA

DE PSICOPATOLOGIA

F U N D A M E TA L ano VI, n. 3, set/ 2003

É um tanto perigoso imbuir-se demais nas teorias do autor; arrisca-se o leitor a tornar-se mais realista que o rei, incluindo Max Nordau no estudo por ele mesmo feito. Facilmente se encontraria apoio para a inclusão do autor das Mentiras Convencionais na Dégénérescence. Se Schopenhauer lá está com o seu pessimismo budista, as Mentiras Convencionais podem servir de cartão de ingresso a seu autor. Creio que o filósofo de Dantzig subscreveria de bom grado esse livro.

Naturalmente a isso responderá ele: não confundam os esputos dos tísicos com as pérolas...

Se o autor de Quincas Borba tivesse escrito o Doutor Bacamarte depois da Degenerescência de Max Nordau, muita gente acreditaria que era uma alusão ao notável escritor. O alienista da Casa Verde, de Itaguahy, por pouco não ficou isolado naquela vila, tendo recolhido como loucos quase todos os habitantes.

Percorrendo os diversos capítulos da Degenerescência acode-nos à mente o terceto de Dante:

\section{Stavvi Minos orribilmente e ringhia}

Esamina le colpe nell'entrata,

Giudica e manda secondo che avvinghia.

Como quer que seja é um livro magnífico; tem capítulos admiráveis, sobretudo em relação à arte em geral, no segundo volume. O defeito do livro, o maior, é o que ele por sua vez nos aponta de E. Zola, no capítulo Zola e sua escola (p. 410, $2^{\circ}$ vol.).

O seu modo errado de interpretar a degeneração provém do princípio falso que lhe serve de base. Afirma ele que a moléstia em essência não se apresenta diferente da saúde, e dá como exemplos ( $2^{\circ}$ vol., p. 558) a criança de berço,

“Oh! A fé que abala montanhas! A fé que se resigna e se submete, que consolação, que alegria, que força! ... Mas como adquiri-la se ela não depende de um esforço de vontade?! Se a ciência não sofreu bancarrota total, sofreu ao menos uma série de bancarrotas parciais. Esclareceu o homem sobre a sua origem e o seu destino? Explicou ao menos as fontes da linguagem da sociedade, das suas normas de procedimento?” (...)

Nada mais doloroso do que ver-se um moço (o referido articulista), de talento tão brilhante e aproveitável, ajoelhando-se e fazendo orações à Virgem de Lourdes, e depois caindo em desalento por não ter sido ouvido. Espírito superior, como inteligência, mas moralmente frágil, desequilibrado. Infelizmente para o catolicismo, as suas conquistas, com que julga fazer figas à ciência, são nesse terreno ou no período pré-agônico de alguns sábios. Já não falamos dos pobres de espírito, porque o reino do céu sempre lhes pertenceu ...

A ciência não sofre nem pode sofrer bancarrota. Quando os homens de talento que, dedicandose a ela, poderiam prestar tanto serviço à humanidade, se apresentam neurastênicos ou degenerados, outros que não são doentes estão aí para fortificá-la. (...) 
que é atáxica, por não ter aprendido a andar, e o tabético, que também é atáxico. Ora, isto é simplesmente um absurdo, mas que pode embair um leitor que não conheça a lesão da tabes; tanto mais que ele apela para o testemunho e consenso do dr. Frenkel. ${ }^{7}$ Abandonando-se, assim, um ou outro despropósito como esse, a Degenerescência é um livro útil.

Há pouco tempo foi publicado por um dos nossos mais finos críticos, C. Laet, um capítulo de crítica sobre a escola de Zola, que muito aproveitará aos apreciadores do romancista (Em Minas, C. Laet, 1895). Não só Zola, mas também os simbolistas têm aí a sua conta.

Antes de tratar das características dos degenerados, é de primeira necessidade conhecer bem a significação de certos termos correntes em psiquiatria.

A obsessão (e não obcecação) é caracterizada pelo aparecimento brusco de uma idéia, ou grupo de idéias, que se impõe à consciência lúcida, sob a forma de paroxismos, interrompendo o curso normal da associação de idéias, apesar de todo o esforço da vontade, cuja incapacidade se manifesta por uma tortura moral intensa.

Dou aqui o exemplo com um doente que estudei há tempo, e do qual tenho a observação escrita: - a idéia obsidente era, neste caso, o suicídio. O estado moral deste doente era desolador: a faca com que comia na mesa; a janela de um primeiro andar em que se achasse; o viaduto, quando por aí passava, tudo provocava a sua idéia, acompanhada dos sinais característicos (emoção) que nunca faltam, isto é, ansiedade, palpitação, palidez e suores, que são sinais de luta moral terrível. Este doente vivia acompanhado de uma pessoa para evitar um desastre.

A impulsão é caracterizada por um ato (ou série de atos) realizado por um indivíduo de consciência lúcida, apesar da intervenção da vontade, cuja impotência se manifesta por uma tortura moral intensa.

Um exemplo fácil se encontra nessas espeluncas aristocráticas, a que chamam Club, mas que são casas de jogo. É preciso não confundir os que jogam para ganhar a vida com os que jogam contra a própria vontade e lutam horrivelmente para se livrarem dessa impulsão. A mesma diferença existe entre o dipsomaníaco e o que bebe por gostar do álcool.

O doente que se perde em explicações complicadas para mostrar que descobriu o moto-contínuo, a direção dos balões, etc., já não está nas mesmas

7. Dizer-se, como Broussais, que o organismo são é regido pelas mesmas leis que o organismo doente, é razoável; mas a comparação e estabelecimento da identidade entre a medula do tabético (esclerosada) e a da criança (em evolução) não é aceitável de modo algum. 
condições do que sofre uma obsessão; é um delirante, cuja consciência está obscurecida e cuja vontade não luta.

Seria aqui o lugar de mostrar a diferença que a escola positivista estabelece entre loucura e alienação. A alienação consiste na impossibilidade em que se acha o indivíduo de harmonizar a sua conduta com a sua situação; o louco é um alienado, mas a recíproca não é verdadeira. ${ }^{8}$

O epiléptico que se atira a um homem e o mata, também não é idêntico ao doente que arranca os olhos a um animal (como fez Edgar Poe ao gato preto, nas Hist. Extraord.).

No epiléptico não existe consciência nem há luta angustiosa da vontade. Os dois fatos podem apresentar-se isolados, ou associados, a impulsão seguindo a obsessão.

Bem compreendido o sentido dessas palavras, tudo mais se torna simples. Todas as fobias (temor) são obsessões, como a claustrofobia, agorafobia, aicmofobia, etc. (O número pode ser indeterminado) - o conteúdo das obsessões pouco importa.

A cleptomania (mania de furto), piromania (de incêndio), omniomania (de compras), etc., são impulsões.

A abulia também é um termo muito usado (- a ausência da vontade para dirigir um ato que o indivíduo precisa realizar). É uma espécie de inibição de um centro psicomotor para um determinado movimento. Esta inibição pode se estender em larga escala, produzindo um caso como o de Thomas Quincey (citado por Th. Ribot, Maladies de la Volonté), que queria publicar a Introduction à tout système d'économie politique, e não lhe foi possível; o caso de Esquirol (Des Maladies mentales, vol. I, p. 421) de um antigo magistrado que não podia querer sair de casa e tratar de seus negócios.

Na melancolia é onde mais facilmente se observa a abulia.

A neurastenia é também acompanhada de abulia em muitos doentes; tal é o caso de Hamlet, que G. Dumas dá como um abúlico (L'état mental des melancholiques, 1895).

Na melancolia a abulia pode ser primitiva ou secundária, segundo Schüle. Th. Ribot (loc. cit.) chega a concluir que a abulia é conseqüência do enfraquecimento geral da sensibilidade, uma diminuição do tonus vital, o que é perfeitamente aceitável, porque é a explicação fisiológica. George Dumas acompanha estas idéias de Ribot. Essas duas obras (de Ribot e de Dumas) devem ser lidas por quem quiser conhecer o assunto. 


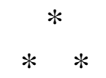

Dizem que os alienistas consideram todo o mundo louco.

Vigouroux

Fazendo algumas considerações que a leitura e a observação me têm sugerido sobre os degenerados, não me desvanece idéia alguma de escrever trabalho didático. Aconselho aos que quiserem conhecer melhor o assunto, os trabalhos de Magnan e Legrain, como os mais metódicos e recheados de observações cuidadosamente colhidas.

Os fatos acima referidos deixam logo ver que é muito mais interessante o estudo desses doentes extra-muros, do que nos Hospícios, para onde só são recolhidos os que, por exageração de sintomas, se incompatibilizam com a sociedade.

A psicologia do idiota e do imbecil pouca coisa contém, ${ }^{9}$ além de mostrar até onde chega o vício orgânico acumulado por herança, e a terminação providencial, por esterilidade, de uma geração arruinada. O interesse do estudo psicológico começa nos fracos de espírito ou débeis, e vai até aos degenerados superiores (Legrain, Du délire chez les dégénerés, 1886). Aí encontramos o louco moral, o impulsivo, os de idéia fixa, etc.

Os pequenos trabalhos, como este, devem ter em vista, sobretudo, as idéias gerais, despidas de particularidades que só aproveitam aos especialistas habituados ao estudo. Assim poderão os leigos formar juízo exato do que os alienistas pensam quando se referem aos degenerados.

Há confusão deplorável em supor que os alienistas consideram louco todo o mundo ... Os alienistas só consideram louco o indivíduo que apresenta um conjunto de caracteres psíquicos e somáticos que indicam uma acumulação de vícios orgânicos por herança. Hoje sabe-se, e é noção exata, que, por herança, as moléstias se transformam de pais a filhos (Moreau de, Tours); sirva de exemplo a tuberculose nos pais a qual pode trazer para os filhos uma perturbação mental (Ch. Féré, Famille Nevropathique). ${ }^{10}$

9. Entretanto, se o leitor tem desejo de ler e conhecer o assunto, é procurar o livrinho de Sollier (Paris, 1890) sobre esse assunto.

10. Para mim está fora de dúvida essa transformação. Tenho observado em duas famílias a alternância da tuberculose com as perturbações nervosas graves. Estas observações são melindrosas porque se referem a clientes particulares da minha prática civil.

- A propósito da herança:

Conheço um fato horroroso, uma das coisas raras e mais monstruosas que é possível: um homem louco uniu-se a uma própria irmã, louca também, e tiveram uma filha: esta é imbecil, mas já está casada com um parente!! Felizmente a natureza se incumbirá de esterilizar o que daí possa sair. 
Outra confusão, que é preciso esclarecer, é a que não permite distinguir o que é inteligência do que é desequilíbrio mental.

Estes dois fatos são de todo independentes. O desequilibrado superior apresenta às vezes, quando pertence ao tipo mais elevado, uma inteligência sublime, incomparável, o que lhe vale o nome de gênio. Leia-se o que disse um doente desses: "Os homens me chamaram louco, mas a ciência não nos disse ainda se a loucura é ou não o sublime da inteligência - se quase tudo que é a glória, tudo que é a profundeza, não vem de uma moléstia do pensamento em detrimento do intelecto geral. Os que sonham acordados vêem mil coisas que escapam aos que só sonham dormindo. ${ }^{11}$ Nas suas visões brumosas eles avistam pedaços do céu e estremecem ao despertar, vendo que estiveram por instantes à beira do grande segredo. Sem governo e sem bússola penetram no vasto oceano da luz inefável, e, imitando os aventureiros do geógrafo nubiano - agressi sunt Mare Tenebrarum quid in eo esset exploraturi” (Edgar Poe, Histórias grotescas: Eleonora).

A expressão, como aí está, é subversivamente extensa. Poe deveria ter dito: a ciência não nos disse ainda se o sublime da inteligência é ou não, algumas vezes, uma forma de loucura. Hoje a ciência responderia afirmativamente.

Pode-se dizer, de um modo geral, que o que distingue os diferentes grupos de degenerados é justamente a inteligência. Nula no idiota, ela começa a esboçarse no imbecil, e já aparece bem mais clara no débil, tomando às vezes, quando chega ao superior, as proporções do sublime. Em razão inversa a essa faculdade encontram-se os estigmas físicos: - grosseiros no idiota e difíceis de se encontrarem no superior.

Note-se que, nessa classificação de caracteres psíquicos, a passagem de uma para outra classe é marcada por uma zona confusa, onde não é fácil distinguir os tipos de cada uma.

Na parte mais elevada dos fracos de espírito encontram-se homens que já representam papel ativo na sociedade: podem ser médicos, bacharéis, engenheiros, etc., chegando mesmo alguns a fazer carreira do Conde de Monte Cristo, ocupando posições elevadas, de onde cometem sandices inqualificáveis. ${ }^{12}$

Nos mais baixos encontram-se os poetas impagáveis ou terrivelmente cacetes, como eu conheço dois; há uma parte do público que os aprecia extraordinariamente - são os estudantes trocistas.

11. O fato é que no Eureka ele aproximou-se muito de questões hoje expostas por H. Spencer nos Primeiros princípios. Apesar de toda a embrulhada metafísica da linguagem, ninguém negará a Poe esse direito.

12. O leitor, à proporção que for lendo, vá procurando nas suas recordações alguns conhecidos seus e os adaptando à fórmula; não tenha receio, a sua vez não chegará... 
É ainda daqui que os governos de algumas majestades tiram proventos distribuindo tetéias e fitinhas para o peito... etc. ${ }^{13}$

Descrever um tipo que seja de padrão, é impossível; a variedade é imensa; disposições de espírito inteiramente opostas encontram-se na mesma classe: uns são egoístas; orgulhosos e estupidamente cheios de si mesmos; outros são em extremo filantrópicos, inventam uma série de tolices em benefício da humanidade, e têm a pretensão, inocente aliás, de se apresentar candidatos a cadeiras de deputados ... e alguns conseguem lá chegar.

Não se confunda ignorante com degenerado débil. Um homem pode não ter instrução e dispor, entretanto, de juízo, de bom senso que lhe permita conhecer claramente a sua posição na sociedade. Eis aí o ponto capital de diferença.

Os degenerados podem ter preparo intelectual muito superior ao de um homem normal, mas este terá o bom senso que falta àqueles. A instrução nos degenerados é, a maior parte das vezes (tratando-se dos débeis), uma bagagem inútil, porque a faculdade de síntese, a dedução, que permite ao homem normal tirar proveito do que aprendeu, quando neles existe, é fraquíssima.

Assim, temos de um modo geral: fraqueza das faculdades de síntese; fraqueza ou mesmo ausência da vontade (esta, se existe, é quase sempre sob a forma de teimosia); superficialidade do exame e da reflexão; sensibilidade moral embotada ou por demais desenvolvida, caindo em exagero oposto; perversões diversas (pederastia, etc.); ${ }^{14}$ agudeza, às vezes, esquisita de uma faculdade elementar, como a memória, quase sempre parcial; imaginação fecunda ... em dispara-

13. Explicação importante. É preciso que se saiba que os homens de mérito real e de valor moral, recebem também fitinhas e comendas, que são distintivos de valor e aos quais se deve respeito. Mas é justamente em prol desse direito que faço a referência supra. Sim! Porque há muitos indivíduos que tendo tido uma taverna, tiveram também energia e força de vontade para comer, durante muito tempo, cebola com pão no almoço e pão com cebola no jantar: enriquecem esses sujeitos e compram, a peso de dinheiro, um distintivo que só deveria ser concedido a homens de valor intrínseco. Deles bem se pode dizer como o padre Vieira: “As comendas em semelhantes peitos não são cruz, são aspa: e, quando se vêm tantos ensambenitados da honra, bem vos podeis honrar de não ser um deles. Virtutem ex me fortunam ex alliis.” (Sermão da $3^{\mathrm{a}}$ quarta-feira da Quaresma, 1669).

É só a esses idiotas que me refiro. Essa venalidade por parte de certos governos, que exploram a idiotia e a imbecilidade, destruindo o efeito estimulante das distinções honrosas, deveria ser fustigada por uma pena como a de Moliére ou Rabelais.

Esse amor pelas tetéias, objetivando o desejo de aparecer como grande, é evidente desde os imbecis de baixa estirpe: um engraxate já se tornou notável em São Paulo por esse fato, não há quem não se lembre de sua figura.

14. Krafft-Ebing descreve uma forma de psicopatia sexual - o masoquismo - que vem de Sacher Masoch, romancista, que descreve certos indivíduos, nos quais as manobras dolorosas pratica- 
tes, ou na produção de idéias sem alcance. Acessíveis ao maravilhoso, de que têm mesmo necessidade, quase todos têm boa letra e especial cuidado em darlhe uma forma elegante. Apresentam ticos, ou movimentos inúteis e involuntários, acompanhados muitas vezes de pronunciação, também involuntária, de uma palavra (palavra espasmódica, ecolalia e coprolalia. - Guinon, Révue de Médic., 1886).

Em relação aos caracteres físicos ou somáticos, temos uma série de anormalidades mais ou menos constantes: assimetria facial, deformação craniana, implantação viciosa dos dentes, formas e colocação anômalas das orelhas, defeitos nos membros ou nos dedos. ${ }^{15}$

Como espécimens de deformidades cranianas, temos no Hospício muitas variedades; e dessas deformações, associadas à maneira especial de delirar, temos nos servido para o diagnóstico, quando a falta de informações nos deixa reduzidos só a isso.

A interrogação duvidosa de Dagonet não tem muito fundamento; acredito, como Legrain, que sempre se pode distinguir por certos caracteres o delírio dos degenerados.

das em si mesmos, por indivíduo do sexo oposto, trazem satisfação do apetite genital. Féré atribui esse fato a uma emotividade mórbida (Pathol. das Emoções, p. 445). Max Nordau reúne a esse grupo um importante personagem da Naná de Zola.

Há ainda nas perversões sexuais, os fetichistas sexuais, indivíduos que não podem ver um lenço de mulher, um vestido ou uma botina, sem serem logo acometidos de orgasmo genital. Não se deve confundir com esse fetichismo o fato de um indivíduo adorar um alfinete, uma flor, etc., que passaram pelas mãos de uma criatura querida (neste gênero, quem não tem sido fetichista?...), a confusão seria muito grosseira.

Veja-se L'homme selon le transformisme de V. de Lima. Nas notas do final do livro ele apresenta fatos que parecem confirmar as teorias de Lombroso sobre o ativismo nos criminosos.

15. Neste gênero temos no Hospício o que há de mais curioso e raro: um degenerado em estado de lipemania atônita, cujas mãos se assemelham tanto às de um macaco, que parece até faltar o movimento de oposição do polegar. O lábio leporino, a anormalidade na forma da abóbada palatina, o estrabismo, etc., tudo se encontra no degenerado. Estas deformidades existem neles na razão direta da imperfeição da inteligência.

- se L'homme selon le transformisme de V. de Lima diz que à fealdade física corresponde a fealdade moral. Não é possível aceitar essa idéia muito ao pé da letra. As proposições desse fisionomista não correspondem sempre à verdade, mas têm dela alguma coisa. (...)

Pela minha prática pessoal só posso dizer que conheço sujeitos que, muito feios, são de boa índole, o que destrói o absolutismo de Lavater. Contra ele também está o Coruja de Aluísio Azevedo e o Quasímodo de V. Hugo. Se há exemplos contrários a Lavater, há também muitos a favor: é linguagem corrente dizer-se: “cara de assassino”, “cara de ladrão” etc.

Como quer que seja, o homem superior, inteligente, tem na fisionomia alguma coisa de simpático e atraente, que não é fácil explicar e dizer o que seja. 


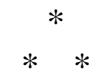

O leitor curioso e inteligente poderá, sem dificuldades, encontrar a cada passo indivíduos da espécie que acima descrevemos. ${ }^{16}$

Falstaffs dessa categoria aí andam pelas ruas sem que ninguém os incomode; não é só no Hospício que são eles encontrados.

Iliados intra-muros peccatur et extra.

As prisões estão recheadas de degenerados impulsivos e de doentes de loucura moral. As sociedades espíritas já nos têm fornecido, no Hospício, diversos exemplares magníficos de débeis. A absoluta falta de exame ou fraqueza de reflexão faz com que os confessionários se encham de pobres de espírito, quando as prédicas de um padre inteligente vêm lhes dizer que a ciência não vale nada.

Quando um louco, por influência sobre um predisposto, consegue incutirlhe no ânimo o seu delírio, tornando-o também louco, dizemos que há fólie à deux. ${ }^{17}$ A explicação para esta espécie é a mesma que para a loucura do confessionário. Está claro que não incluo neste número os que com sinceridade acreditam em tudo o que diz a Igreja, os que têm ainda o espírito no período teológico; esses podem ser moralmente bem equilibrados. Refiro-me somente aos que já se tendo libertado das crendices, voltam a elas sob a influência de um

16. Embora o desejo de guardar silêncio sobre alguma coisa, me tenha feito vacilar, não posso deixar de me referir a uma classe muito curiosa - a dos paradisíacos. Esta aplicação do termo, se for imprópria, sou eu o único responsável, porque é lembrança exclusivamente minha, em honra ao pai Adão.

- “Généralise par la pensée le renoncement à soi-même et tu verras que c'est la destruction de la Société,” diz Bastiat (citado por Féré).

- Há uma classe de indivíduos, muito mais comum do que parece à primeira vista, que vive sem fazer absolutamente nada! Essa classe se subdivide: há os ricos, que tendo recebido uma fortuna, que não custou o seu suor, comem os rendimentos ou mesmo um pouco do capital, dando como desculpa à própria inépcia, à própria esterilidade, o fato de serem ricos e não precisarem fazer nada. Sim senhores! É a fidalguia suína mais completa: têm com que se alimentar ... e são ricos!

- Essa espécie é abundante.

- A outra espécie é menos numerosa, a dos que não têm nada e não fazem nada. Conheço muito poucos exemplares, mas é provável que haja muito mais. O ponto de contato que une as duas espécies é o fato de não moverem nem uma palha com um fim útil (também não fazem mal a ninguém, a não ser consumir sem produzir).

Vivem como o personagem de Rabelais, o pai de Pantagruel, na sua adolescência: à boire, manger et dormir, à manger, dormir et boire, á dormir, boire et manger.

17. Loucura comunicada (Falret e Laségue, Arc. Gen. De Médicine, 1877). 
discurso incompreensível; a esses, que não têm convicção alguma, é que se aplicam as observações psiquiátricas. ${ }^{18}$

Para encurtar considerações, lembro, como já disse, que os tipos variam muito, mas em todos eles encontram-se alguns ou todos os característicos indicados.

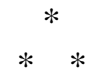

Passando aos degenerados superiores, nada podemos ver nas observações do Hospício. Só o lado triste da vida desses homens é que encontramos nos respectivos apontamentos. É na literatura, na vida íntima dos grandes artistas, que os psicólogos têm encontrado elementos para completar semelhantes estudos.

Estes doentes são completamente diferentes dos da classe precedente pela inteligência, mas ... têm pontos de contato que é impossível negar, que dão na vista até do público ignorante, que os denomina pancadas.

Não posso dar um exemplo mais completo, mais convincente, do que o Mauvais Vitrier de Baudelaire (Petits poèmes en prose). Aí a impulsão dos degenerados, a impulsão admiravelmente caracterizada pela existência da consciência, pela irresistibilidade ao ato e satisfação pela descarga nervosa, é exposta com inteligência superior e espírito finíssimo.

Como deveria ser agradável a convivência íntima com Baudelaire! Só quem não conhece a verve maravilhosa dos artistas não lhes dá valor à sua íntima palestra! Quem já conviveu com artistas sente forçosamente saudades cruéis desse tempo; todos que têm tido esse prazer na vida sentem lá um dia, no meio das lutas pela existência, uma sombra de tristeza, um aperto no coração ao lembrarem-se de uma certa época da existência passada.

Voltando ao Mauvais Vitrier, o grande literato não só apresenta a impulsão muito bem compreendida, como dá também, em poucas, mas admiráveis frases, os traços característicos da melancolia. Reproduzo aqui alguma coisa para tornar a apreciação mais fácil: "Il y a des natures purement contemplatives et tout à fait impropres à l'action, qui cependant, sous une IMPULSION MYSTERIEUSE ET UNCONNUE, agissent quelquefois avec une rapidité dont elles se seraient crues elles-mémes incapables".

Depois de agradabilíssimas e espirituosas considerações, conta como atirou ao chão com um tabuleiro de objetos de vidro, comparando o ruído ao de um palácio de cristal sob a tremenda ação de um raio. E termina dizendo: "Mais qu’importe l'éternité de la damnation, à qui a trouvé dans une seconde l’infini de la jouissance!”

18. Há um grande número de indivíduos que estão com as idéias constantemente em movimento: estão sempre de acordo com o último livro que leram ou com o último discurso que ouviram. 
Essa produção literária basta para caracterizar o autor como um impulsivo, embora seja ele uma inteligência superior. ${ }^{19}$

Quem se der ao trabalho de estudar, por curiosidade, a arte, a literatura e mesmo a ciência, encontrará tantos exemplos, que forçosamente se convencerá da verdade. Desde Sócrates até hoje os exemplos são inúmeros. Os estudos de Lombroso nesta espécie, são os mais conhecidos e instruirão com muita vantagem os que quiserem se dedicar a isso (Lombroso, trad. franc., L’homme de génie).

A emotividade e a impressionabilidade, que são condições essenciais ao artista de raça e ao gênio (em qualquer das suas manifestações), são também as causas dos desvios monstruosos do tipo anormal. Eles, os artistas, caracterizamse na sociedade por constantes revoltas contra as leis da moral vigente. São estéreis e se anulam por incapacidade orgânica de adaptação ao meio em que vivem.

Ch. Féré (Patologia das emoções, p. 529) diz que a nevropatia aparece com insistência muito maior nos homens de gênio de certa espécie - guerreiros, fundadores de religiões e artistas - cuja utilidade social não é evidente; e que na história da vida dos homens úteis de gênio, a nevropatia tem sido pouca coisa. Esta última afirmativa é verdadeira, mas a primeira contém um tópico com o qual respeitosamente não concordo; que a utilidade dos fundadores de religiões e artistas não é evidente.

Os costumes, a grandeza de sentimentos e a moral de um povo são, não há como negar, influenciados beneficamente pela arte e pela literatura, contanto que estas sejam boas e elevadas.

Dizer-se que em certas épocas o fanatismo religioso tem sido empecilho à ciência, ${ }^{20}$ não é dizer-se que a religião não tem tido influência benéfica em outras ocasiões.

Passado este parêntese, continuemos nos caracteres gerais dos degenerados superiores. É impossível, como já vimos para os débeis, descrever um tipo que sirva de norma; seria descrever uma monstruosidade, contendo em si tanta maldade e tanta bondade que o espírito repeliria com certeza.

Em relação à inteligência, encontram-se variedades desde o talento (não raro) até ao gênio (raríssimo).

19. O mesmo autor tem apreciações sedutoras sobre o haxixe e o vinho, e a tradução de uns escritos de Quincey, que não aconselho a ninguém que leia.

20. Em Salamanca durante muito tempo foi proibido o ensino das teorias de Newton, porque não estavam de acordo com a religião (Lombroso e Laschi, Crime político e revoluções, $1^{\circ}$ vol.). Fatos como esses há muitos, que hoje são conhecidos. 
Grandeza d'alma até o limite máximo, em uns; mesquinhez sórdida e inqualificável em outros. Imaginação viva e ardente, retórica sem igual, postas a serviço de idéias aparentemente grandes, mas inúteis na prática - eles mesmos são as primeiras vítimas, consumindo fortunas e arruinando as próprias famílias. ${ }^{21}$

Isso é resultado de uma característica que quase nunca lhes falta: a superficialidade de exame e de reflexão, a incapacidade de fixar a atenção e de percorrer todas as faces de uma questão. Insuficiência da vontade, inconstância em tudo, que faz com que alguns aprendam vinte ofícios, estudem mil coisas, e afinal nada saibam bem. Precocidade notável, que os distingue dos débeis; um superior aparece às vezes fazendo prodígios aos 12 ou 13 anos de idade, nos colégios ou liceus, tirando os primeiros prêmios, e, fato curioso, mostrando-se excessivamente preguiçoso. ${ }^{22}$

As eivas destes indivíduos são tanto mais notáveis, quanto mais elevadas são algumas das suas faculdades.

Adquirem uma popularidade extraordinária em virtude de certos dons (oradores, escritores, médicos, etc.) e tornam-se, com a sua maneira falsa de ver as coisas, as criaturas mais perniciosas da sociedade. ${ }^{23}$

21. Em relação às idéias de grandeza que se notam em quase todos os poetas de gênio, não acho muita razão no exagero de Lombroso. É muito natural que um homem que se percebe superior, tenha alguma vaidade do seu talento, desde que não exceda de certo limite. (...)

22. A propósito, seja-me permitido observar que há moços de talento e muito aproveitáveis, que fazem figura nas Academias como literatos, mas que infelizmente permanecem nesse statu quo depois de formados; tornam-se vulgares e sem valor nenhum.

Todo o homem que quiser aparecer na literatura não deve começar na mocidade pelas leituras inúteis; deve em primeiro lugar adquirir um preparo científico regular e só depois enriquecer esses conhecimentos com a leitura de boas obras literárias. Um Taine não se faz com simples leitura de versos e romances. Os que procedem de outro modo, escrevem coisas que se parecem com as bolhas de sabão, porque só conhecem a literatura fácil de poemas e romances ... e disse.

Conheci um que só falava em Ivan Turgeniev, e em cujo rosto se lhe pintava imensa satisfação quando percebia que muitos dos circunstantes não conheciam coisa alguma da literatura eslava ...

23. A nocividade dessa gente é incontestável e fácil de demonstrar. Quase sempre são bons oradores ou bons escritores (bons pela inteligência viva e pelas palavras arrebatadoras), mas sem critério, sem juízo, sem discernimento; atacam as questões por um só lado e deixam-se arrastar por isso a conseqüências desastrosas de um exame superficial.

Dentre o público se pode contar a dedo os que analisam o palavrório desses sujeitos. A maioria aceita-os e sofre inocentemente todas as conseqüências. É assim que se explica a supremacia de muitos desses indivíduos. Entre os seus apreciadores muitos há que, percebendo o domínio franco desses indivíduos, velhacamente se chegam a eles, para tirar proveito dessa posi- 
Se um grande número de pobres de espírito se aventura em questões insolúveis e altos problemas científicos, como o motu-continuo, a direção dos aerostatos, etc., também nos degenerados superiores encontramos tipos correspondentes a esses: tais são os políticos, que esquecendo-se completamente da lei normal do progresso, querem fazer tudo aos pulos, indo de encontro às idéias conservadoras da maioria (Misoneismo, de Lombroso e Laschi).

Querer um fim sem os meios - eis o traço característico de todos eles. Tenho um doente que quer fazer um livro de poesias, para deixar aos filhos como fortuna; entretanto, mal sabe ler. Tenho um outro que descobriu um olho d'água, com que pretende resolver o motu-continuo por meio de um complicado mecanismo que não se pode compreender. Conheço um outro que pretende escrever toda sua vida num livro de 600 páginas, quer será um magnífico romance, mas ... é quase analfabeto.

A obsessão, a idéia fixa, a impulsão e a aberração sexual no que ela tem de mais monstruoso, são os estigmas comuns nos degenerados superiores, e que os colocam a par dos débeis e dos imbecis.

Mais uma qualidade distingue esses indivíduos do resto da humanidade: a facilidade com que entram em delírio. Alguns há, entretanto, que passam a vida inteira sem delirar, porque não lhes aparece uma causa provocadora. Uma grande parte, em busca de condições orgânicas especiais, atira-se ao álcool e a outros venenos cerebrais (haxixe, ópio, etc.), acabando a vida nos hospícios, no meio dos horrores de alucinações sensoriais penosas.

ção; submetem-se servilmente às suas idéias, ainda que intimamente sejam contrários às asneiras que os grandes homens cometem.

Tenho uma série de fatos muito interessantes sobre esse assunto, e reservo-os para um estudo mais cuidadoso, quando o tempo me permitir. 